Short communication

\title{
Phytic acid protects porcine intestinal epithelial cells from deoxynivalenol (DON) cytotoxicity
}

\author{
Graziela Drociunas Pacheco ${ }^{a}$, Caio Abércio da Silva ${ }^{a}$, Philippe Pinton ${ }^{\mathrm{b}}$, \\ Isabelle P. Oswald ${ }^{\mathrm{b}}$, Ana Paula Frederico Rodrigues Loureiro Bracarense ${ }^{\mathrm{a}, *}$ \\ a Universidade Estadual de Londrina, Centro de Ciências Agrárias, Campus Universitário, Londrina, CX Postal 6001, Brazil \\ ${ }^{\mathrm{b}}$ INRA, Laboratoire de Pharmacologie-Toxicologie, 180 Chemin de Tournefeuille BP3, 31931 Toulouse, France
}

\section{A R T I C L E I N F O}

\section{Article history:}

Received 12 August 2010

Accepted 27 September 2010

\section{Keywords:}

Intestinal cell

Inositol

$\mathrm{IP}_{6}$

Mycotoxin

Toxicity

\begin{abstract}
A B S T R A C T
The purpose of this study was to evaluate the effects of phytic acid $\left(\mathrm{IP}_{6}\right)$ as a possible inhibitor of cellular damage induced by toxic substances such as mycotoxins on a porcine intestinal epithelial cell line (IPEC1). We first observed that a dose of $5 \mathrm{mM}$ phytic acid decreases cell viability and transepithelial electrical resistance (TEER) of cell monolayer. We next investigate the effect of non-cytotoxic dose of phytic acid on the deoxinivalenol (DON) induced decreased TEER. We showed that treatment with $0.5 \mathrm{mM}$ or $1.0 \mathrm{mM}$ phytic acid restores the decrease in TEER caused by $25 \mu \mathrm{M}$ DON. In conclusion this study demonstrates that phytic acid decreased the negative effects of deoxynivalenol on the membrane integrity of the IPEC- 1 intestinal epithelial cell line.
\end{abstract}

(c) 2010 Elsevier GmbH. All rights reserved.

\section{Introduction}

Phytic acid is a highly phosphorylated molecule present in cereal grains and seeds. It serves as the major form of storage of phosphorus in the seed as well as being a natural antioxidant (Graf \& Eaton, 1993). It is found in most mammalian cells, wherein it is important in regulating vital cellular functions such as signal transduction, cell proliferation and differentiation (Szwergold et al., 1987; Shamsuddin et al., 1997).

Mycotoxins are toxic secondary metabolites produced by fungi that may contaminate animal and human food at all stages of the food chain (Oswald et al., 2005). DON is a type of $\beta$-trichothecene that is mainly produced by Fusarium graminearum and Fusarium culmorum, which are found naturally worldwide, and their cytotoxicity has been demonstrated in animals and various kinds of cells (Zhang et al., 2009). It is known that DON disrupts the functions of cellular membranes (Bunner \& Morris, 1988) and alters the intercellular communication (Khera et al., 1982). A decrease in trans-epithelial electrical resistance was observed by Pinton et al. (2009) and Van De Walle et al. (2010).

In fact, studies have demonstrated that trichothecenes stimulate lipid peroxidation, however the dietary use of antioxidants can pro-

\footnotetext{
* Corresponding author at: Universidade Estadual de Londrina, Centro de Ciências Agrárias, Departamento de Medicina Veterinária Preventiva, Campus Universitário, Londrina, CX Postal 6001, Brazil. Tel.: +55 433371 4062; fax: +55 4333714714.

E-mail addresses: anauel02@yahoo.com.br, ana.bracarense@pq.cnpq.br (A.P.F.R.L. Bracarense).
}

vide protection against cell damage. In this study, we used a porcine intestinal epithelial cell line to determine the effects of phytic acid and DON on intestinal epithelial integrity.

\section{Materials and methods}

\subsection{Cell culture and reagents}

The Intestinal Porcine Epithelial Cells (IPEC-1) cell line is a newborn swine intestinal epithelial cell line that was derived from the small intestine of a newborn unsuckled piglet. The cell lines were maintained by serial passages as previously described (Bouhet et al., 2004). Purified DON (Sigma, St Quentin Fallavier, France) was dissolved in DMSO and stored at $-20^{\circ} \mathrm{C}$ before dilution in cell culture media. Inositol hexaphosphate (phytic acid sodium salt hydrate purchased from Sigma-Aldrich Co.) was dissolved in sterilized water $(0.4 \mathrm{~g} / \mathrm{mL})$ and stored at $-20^{\circ} \mathrm{C}$ before dilution in cell culture media.

\subsection{MTS bioassay}

The effects of phytic acid on the viability of IPEC- 1 cells were studied in a colorimetric assay using the CellTiter $96^{\circledR}$ Aqueous Non-Radioactive Cell Proliferation Assay Kit (Promega Charbonnières, France). IPEC-1 cells were seeded at a concentration of $5 \times 10^{3}$ cells/well in $100 \mu \mathrm{L}$ of adequate medium in flat-bottomed 96-well plates (Polylabo-Nunc). After culturing for $24 \mathrm{~h}$, various concentrations of phytic acid (0; 
$0.5 ; 1.0 ; 2.5$ and $5.0 \mathrm{mM}$ ) were prepared, pH-adjusted with $\mathrm{NaOH}$ to 7.0 and sterilized by passing through a $0.22-\mu \mathrm{m}$ membrane filter. Subsequently, the solutions were added to the cells. After $48 \mathrm{~h}, 20 \mu \mathrm{L}$ of a freshly prepared MTS/PMS [3-(4,5-dimethylthiazol-2-yl)-5-(3-carboxymethoxyphenyl)-2-(4sulfophenyl)-2H-tetrazolium/phenazine methosulfate] solution was added to the wells, and the cells were further incubated for $2-4 \mathrm{~h}$. The amount of soluble formazan produced by cellular reduction of the MTS was measured by the absorbance at $492 \mathrm{~nm}$ on an ELISA plate reader (Spectra thermo, Tecan, Trappes, France).

\subsection{Measurement of transepithelial electrical resistance (TEER)}

Differentiated IPEC- 1 cells were then treated with $0 ; 0.5,1.0$ and $5.0 \mathrm{mM}$ of phytic acid. After further culturing for $24 \mathrm{~h}$, the TEER was measured. After measuring, the cells were treated with $25 \mu \mathrm{M}$ of DON. After $24 \mathrm{~h}$ of culture, the TEER was measured again. Experimental TEER values were expressed as $\mathrm{kOhms} \times \mathrm{cm}^{2}$.

\subsection{Statistical analysis}

Data were analyzed with Statview software, version 5.0 (SAS Institute Inc., Cary, NC), using ANOVA and PLSD Fisher test. $P$ values $<0.05$ were considered significant.

\section{Results}

\subsection{Phytic acid decreases the cell viability and TEER in a} dose-dependent manner

The effect of phytic acid on cell viability was investigated via MTS assay. The conversion of tetrazolium salt to colored formazan by succinate dehydrogenase, the main mitochondrial enzyme, is proportional to the number of living cells. In the present study, we searched for a non-cytotoxic dose of phytic acid. The results presented in Fig. 1 demonstrate that phytic acid decreased the viability of the IPEC- 1 cell line in a dose-dependent manner. A significant decrease in cell viability was noted at a concentration of $5 \mathrm{mM}$ phytic acid. The effect of phytic acid treatment was also determined on differentiated cells. IPEC-1 cells were seeding in trans well system and allow to differentiate for 14 days before phytic acid was added on the apical part of the monolayer. Changes in TEER are indicative of alterations in epithelial barrier function or in the tran-

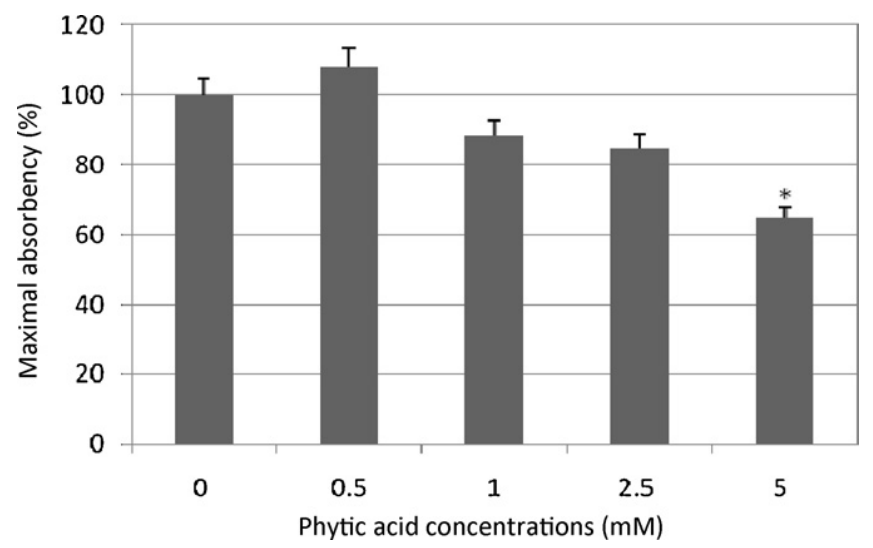

Fig. 1. Effects of phytic acid on cell viability of IPEC-1 cell line as measured by the MTS assay. IPEC- 1 cells were seeded at low density in 96-multiwell plates, allowed to adhere, and then treated for $48 \mathrm{~h}$ with increasing concentrations of phytic acid The amount of soluble formazan produced by cellular reduction of the MTS was then measured by absorbance at $492 \mathrm{~nm}$. Values are expressed as the percentage of the maximal absorbance observed in untreated cultures, mean $\pm S D$ of seven independent wells. Statistical significance between treated culture and control is shown with ${ }^{*} p<0.05$

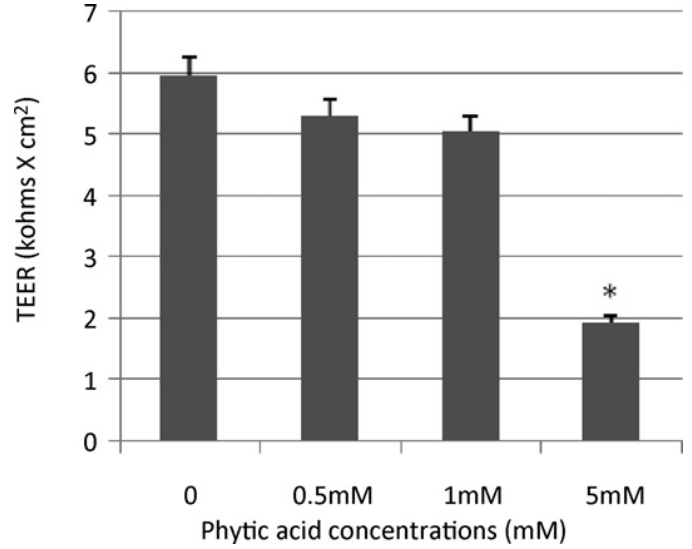

Fig. 2. Effect of phytic acid on trans-epithelial electrical resistance (TEER) in polarized intestinal epithelial cell monolayers. IPEC-1 cells were grown and differentiated on inserts then at day 0 concentrations of phytic acid $(0.5,1.0$ and $5.0 \mathrm{mM})$ were added in the apical compartiment. After $24 \mathrm{~h}$ the TEER was measured. The values are expressed in kohms $\times \mathrm{cm}^{2}$ as the mean \pm SD of 10 independent experiments. $p<0.001$.

scellular permeability of ions. After $24 \mathrm{~h}$ of treatment (Fig. 2), we observed that the TEER values in the control and the treatments with $0.5 \mathrm{mM}$ and $1 \mathrm{mM}$ phytic acid did not differ. On the other hand, IPEC- 1 cells treated with $5 \mathrm{mM}$ of phytic acid exhibited a significantly $(P<0.001)$ lower TEER value when compared with the other treatments. This confirms that the phytic acid at this concentration affected the integrity of intestinal epithelial cell monolayers, a finding also observed in the cell viability test.

\subsection{Phytic acid restores the negative effects of DON on the membrane integrity of IPEC-1}

Previous studies demonstrated that the IPEC- 1 cells treated with DON $(25 \mu \mathrm{M})$ for $24 \mathrm{~h}$ exhibited a significant decrease in the TEER values (Pinton et al., 2009; Van De Walle et al., 2010). The pretreatments of cell monolayer for $24 \mathrm{~h}$ with $0.5 \mathrm{mM}$ or $1.0 \mathrm{mM}$ of phytic acid were able to partially restore $(P<0.001)$ the decreased TEER values induced by DON (Fig. 3). This result indicates that phytic acid may prevent the toxic effect induced by DON.

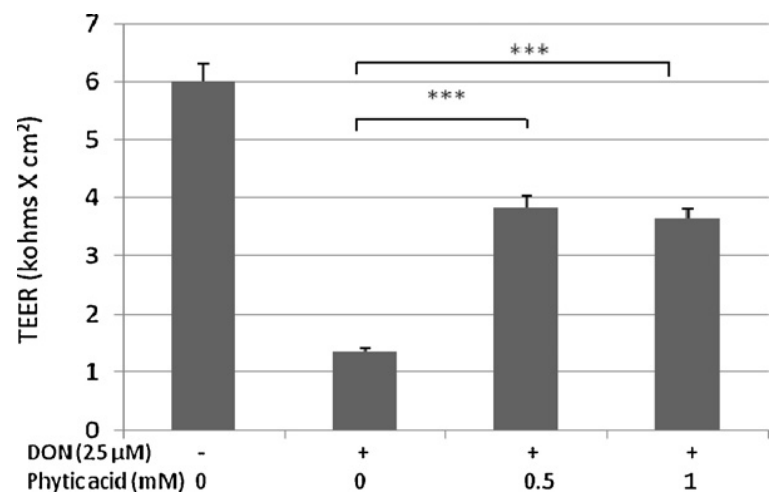

Fig. 3. Protective effect of phytic acid on DON-induced decreased trans-epithelial electrical resistance (TEER) in polarized intestinal epithelial cell monolayers. IPEC-1 cells were grown and differentiated on inserts then at day 0 various concentrations of phytic acid $(0.5$ and $1.0 \mathrm{mM})$ were added in the apical compartiment. After $24 \mathrm{~h}$, $25 \mu \mathrm{M}$ of DON was added in the apical compartiment and the TEER was measured again after others $24 \mathrm{~h}$. The values are expressed in kohms $\times \mathrm{cm}^{2}$ as the mean $\pm S D$ of 10 independent experiments. ${ }^{* * *} p<0.001$. 


\section{Discussion}

An important function of gastrointestinal epithelia is to provide a barrier against the penetration of food contaminants and pathogens present in the intestinal lumen (Arrieta et al., 1996; Oswald, 2006). Several components present in plants are capable of interfering with both bacterial ecology and the immune response of the gut to food antigens. Beneficial nonnutrients, such as antioxidants, occur in foods of plant origin (Weglarz et al., 2007). Thus, the intake of foods high in phytic acid may indirectly influence health. In the present study, phytic acid decreased the viability of the IPEC1 cell line in a dose-dependent manner. A significant decrease in cell viability was noticed at a concentration of $5 \mathrm{mM}$ phytic acid. This result agrees with Weglarz et al. (2007), who evaluated the effect of phytic acid on the growth of Caco-2 cells.

In order to evaluate the effect of a non-cytotoxic dose of phytic acid on DON exposed cells, we used a concentration of $25 \mu \mathrm{M}$ DON. We found that DON decreased the TEER values, which is a good indicator of the epithelium integrity. Similar result was observed by Pinton et al. (2009) who used various concentrations of DON ranging between 5.0 and $50 \mu \mathrm{M}$ in a polarized intestinal epithelial cell monolayer. The protective effect of $\mathrm{IP}_{6}$ was suggested based on its antioxidant effect and its ability to alter cell signaling pathways or antioxidant enzymes that detoxify the reactive oxygen species (ROS) (Shamsuddin et al., 1997). Phytic acid and its hydrolysis products $\left(\mathrm{IP}_{5}, \mathrm{IP}_{4}, \mathrm{IP}_{3}, \mathrm{IP}_{2}\right.$ e $\left.\mathrm{IP}_{1}\right)$ are still able to protect the biological membranes against lipid peroxidation (Miyamoto et al., 2000).

In the present study, phytic acid at a concentration of $0.5 \mathrm{mM}$ or $1.0 \mathrm{mM}$ protected the membranes of the IPEC- 1 intestinal epithelial cell line against cell damage induced by the mycotoxin DON. The administration of products rich in phytic acid in food or feed, such as co-products derived from maize and rice, may act endogenously, protecting cellular systems against the effects caused by substances that induce cellular damages, such as mycotoxins, reducing the negative effects caused by toxins. Thus, losses in animal production and health problems will decrease considerably. However, further studies are needed to confirm the effects of cellular oxidative stress produced by DON in the intestinal IPEC- 1 cells and how phytic acid can effectively minimize these effects.
In conclusion, our results indicate that phytic acid affects cell viability at a concentration of $5 \mathrm{mM}$, but $0.5 \mathrm{mM}$ and $1 \mathrm{mM}$ phytic acid decreased the negative effects of deoxynivalenol on the membrane integrity of the IPEC-1 intestinal epithelial cell line.

\section{Acknowledgement}

This study was supported in part by Grant 593/08 from CAPES/COFECUB, Brazil/France.

\section{References}

Arrieta MC, Bistritz L, Meddings JB. Alterations in intestinal permeability. Gut 1996;55:1512-20.

Bouhet S, Hourcade E, Loiseau N, Fikry A, Martinez S, Roselli M, Galtier P, Mengueri E, Oswald IP. The mycotoxin fumonisin B1 alters the proliferation and the barrier function of porcine intestinal epithelial cells. Toxicol Sci 2004;77:165-71.

Bunner DL, Morris ER. Alteration of multiple cell membrane functions in L-6 myoblasts by T-2 toxin: an important mechanism of action. Toxicol Appl Pharm 1988;92:113-21.

Graf E, Eaton JW. Suppression of colonic cancer by dietary phytic acid. Nutr Cancer 1993;19:11-9.

Khera KS, Whalen C, Angers G, Vesonder RF, Kuiper-Goodman T. Embryotoxicity of 4-deoxynivalenol (vomitoxin) in mice. B Environ Contam Tox 1982;29:487-549.

Miyamoto S, Kuwata G, Imai M. Protective effect of phytic acid hydrolisis products on iron-induced lipid peroxidation of liposomal membranes. Lipids 2000;35:1411-4

Oswald IP, Marin DE, Bouhet S, Pinton P, Taranu I, Accensi F. Immunotoxicological risk of mycotoxins for domestic animals. Food Addit Contam 2005;22:354-60.

Oswald IP. Role of intestinal epithelial cells in the innate immune defence of the pig intestine. Vet Res 2006;37:359-68.

Pinton P, Nougayrède JP, Del Rio JC, Moreno C, Marin DE, Ferrier L, Bracarense AP, Kolf-Clauw M, Oswald IP. The food contaminant deoxynivalenol, decreases intestinal barrier permeability and reduces claudin expression. Toxicol Appl Pharm 2009;237:41-8.

Shamsuddin AM, Vucenik I, Cole K. Minireview-IP6: a novel anticancer agent. Life Sci 1997;61:343-54.

Szwergold BS, Graham RA, Brown TR. Observation of inositol pentakis- and hexakis-phosphates in mammalian tissues by 31P NMR. Biochem Bioph Res Co 1987;264:874-81.

Van De Walle J, Sergent T, Piront N, Toussaint O, Schneider YJ, Larondelle Y. Deoxynivalenol affects in vitro intestinal epithelial cell barrier integrity through inhibition of protein synthesis. Toxicol Appl Pharm 2010;245:291-8.

Weglarz L, Wawszczykj, Orchel A. Phytic acid modulates in vitro IL-8 and release from colonic epithelial cell stimulated with LPS and IL-1 $\beta$. Digest Dis Sci 2007; 52:93-102.

Zhang X, Liping J, Chengyan G, et al. The role of oxidative stress in deoxynivalenolinduced DNA damage in HepG2 cells. Toxicon 2009;54:513-8. 